\title{
Imposex in two sublittoral neogastropods from the Kattegat and Skagerrak: the common whelk Buccinum undatum and the red whelk Neptunea antiqua
}

\author{
Jakob Strand*, Jens A. Jacobsen \\ National Environmental Research Institute, Department of Marine Ecology, PO Box 358, 4000 Roskilde, Denmark
}

\begin{abstract}
Imposex development in female whelks (Prosobranchia: Neogastropoda) has been suggested as a bioindicator of tributyltin (TBT) pollution in the marine environment. The occurrence of imposex in the common whelk Buccinum undatum and the red whelk Neptunea antiqua in sublittoral areas of Danish waters was related to organotin levels. In contrast, imposex was absent in reference material of $N$. antiqua collected in the area before 1938. The concentrations of TBT in whole body tissue of $B$. undatum ranged from $<0.2$ to $3.1 \mathrm{ng} \mathrm{Sn} \mathrm{g}^{-1}$ and total butyltin $\left(\sum \mathrm{BT}=\mathrm{TBT}+\mathrm{DBT}+\mathrm{MBT}\right)$

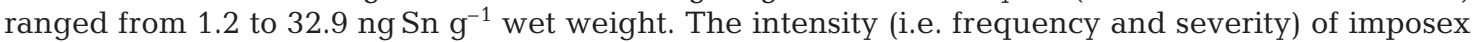
was generally higher in $N$. antiqua than in B. undatum. At 14 stations in the Kattegat and Skagerrak, imposex was present in 9 to $89 \%$ of $B$. undatum and 67 to $100 \%$ of $N$. antiqua. $N$. antiqua seems to be more sensitive to TBT and would thus be the better bioindicator.
\end{abstract}

KEY WORDS: Imposex $\cdot$ Tributyltin $\cdot$ TBT $\cdot$ Buccinum $\cdot$ Neptunea $\cdot$ Denmark

\section{INTRODUCTION}

The imposex phenomenon in gastropods has been described as a superimposition onto females of male sexual characteristics (Smith 1971), such as a penis homologue and/or a vas deferens. It was first observed in 1969 in British populations of the tidal neogastropod Nucella lapillus (Blaber 1970), and subsequently in several other gastropod species. Imposex has now been observed in about 120 species of gastropods (Prosobranchia) worldwide, of which the majority are marine species (Oehlmann et al. 1996). Tributyltin (TBT) from antifouling paints may cause these abnormalities at concentrations as low as $1 \mathrm{ng} \mathrm{Sn} \mathrm{l}^{-1}$ (Gibbs et al. 1987) by disrupting the balances between steroid hormones (Matthiessen \& Gibbs 1998).

In Denmark, as in most of the North Sea countries, the use of TBT as a biocide in antifouling paints was

*Email: jak@dmu.dk restricted around 1990 to boats more than $25 \mathrm{~m}$ in length. This has resulted in decreasing intensity of imposex in British coastal populations of Nucella lapillus (Evans et al. 1995). TBT is, however, still applied on larger vessels. The imposex phenomenon is especially prevalent around hot spots like harbours, but it is also present at considerable distances from these areas. In the offshore waters of the southern North Sea, there seems to be a relationship between the intensity of commercial shipping traffic and the occurrence of imposex in the common whelk Buccinum undatum (ten Hallers-Tjabbes et al. 1994). A study by Ide et al. (1997) demonstrated the presence of imposex and organotin accumulation in $B$. undatum and the red whelk Neptunea antiqua at offshore stations of the North Sea and Irish Sea, indicating the widespread occurrence of TBT.

The aims of this study were to map the imposex intensities of Buccimun undatum and Neptunea antiqua in Danish waters and relate them to the total body burden

(C) Inter-Research $2002 \cdot$ www.int-res.com 


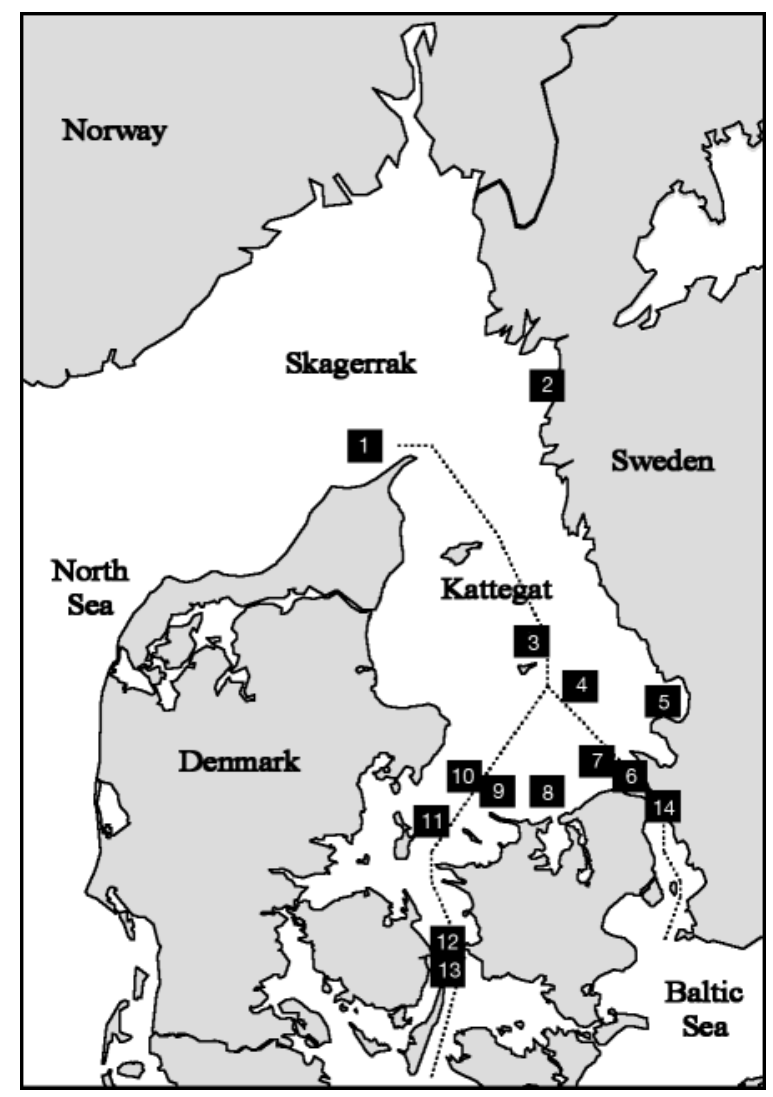

Fig. 1. Buccinum undatum and Neptunea antiqua. Sampling stations 1996 to 1998. Dotted lines indicate international shipping lanes

of organotin compounds. The area of focus was the Skagerrak and southern Kattegat including the northern parts of The Sound and the Great Belt, where more than 50000 ships $>50$ gross tons cross every year (Danmarks Statistik 1997), and numerous ferries operate.

\section{MATERIALS AND METHODS}

Sampling. The common whelk Buccinum undatum $(\mathrm{n}=622)$ and the red whelk Neptunea antiqua $(\mathrm{n}=$ 284) were sampled from June 1996 to April 1998 at 13 stations in the Kattegat including the northern parts of The Sound and the Great Belt (10 to $40 \mathrm{~m}$ depth) and at 1 station in the Skagerrak (70 to $77 \mathrm{~m}$ depth) as shown in Fig. 1 and Table 1. For stations visited more than once during the period, all collected whelks were regarded as 1 sample. At 9 of the stations the whelks were caught using a beam trawl $(2 \mathrm{~m}$ wide, $20 \mathrm{~mm}$ mesh); at Stns 2, 4, 10 and 11, divers collected the whelks by hand. Stns $1,3,4,6,7$, and 9 to 14 were located near important shipping lanes, and Stns 11 to 14 are additionally located near major ferry routes.
Stns 5 and 8 were located at distances of more than 10 nautical miles from the traffic lanes, and Stn 2 was located outside a harbour.

The whelks were frozen immediately after sampling and stored at $-20^{\circ} \mathrm{C}$ until determination of shell height, sex, maturity and imposex characteristics. The shells were cracked open using a pair of pliers. Only adult whelks with visible yellow-red gonads and without infections of trematodes were included in the results. Soft body tissue was wrapped in aluminium foil and stored frozen $\left(-20^{\circ} \mathrm{C}\right)$ until organotin analysis.

A reference material of 6 female Neptunea antiqua collected between 1900 and 1938 in the Kattegat, which were conserved in formaldehyde and stored in $70 \%$ ethanol at the National Zoological Museum, were investigated for possible imposex characteristics.

Imposex determination. For each station, imposex intensities were characterised by percent frequency, by a Vas Deferens Sequence Index (VDSI) according to Stroben et al. (1992), and by a Penis Classification Index (PCI) developed from the descriptions by Mensink et al. (1996a) of the stages in Buccinum undatum. VDSI and PCI describe the overall severity of

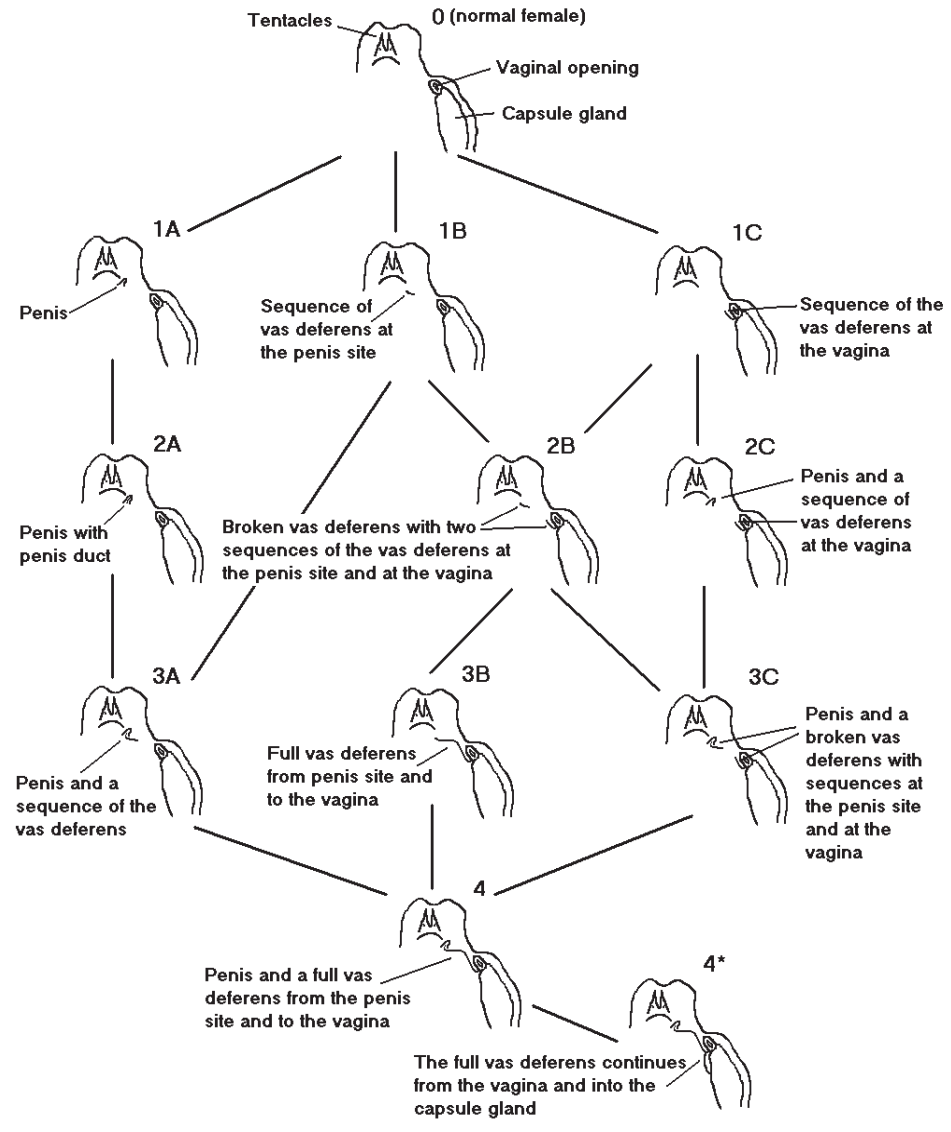

Fig. 2. Scheme for imposex classification with the Vas Deferens Sequence Index (VDSI) 
imposex in a sample, based on average values. PCI stages are increased by 0.5 points if a partial or complete vas deferens is present in addition to the penis homologue. Neither B. undatum (Mensink et al. 1997) nor $N$. antiqua (this study) are mechanically sterilised by the development of imposex, as observed in the muricid Nucella lapillus (Gibbs et al. 1987), in which a highly developed vas deferens blocks the genital pore and prevents the release of egg capsules. The maximum values of VDSI and PCI in species of Buccinidae such as B. undatum and Neptunea antiqua are 4.0 and 3.5, respectively. Classifications of imposex stages used in calculations of VDSI and PCI are schematically described in Figs. 2 \& 3 .

Organotin determination. For each station, 1 to 3 different samples of homogenised (Ultraturrax ${ }^{\circledR}$ ) pools of whole body tissue of 3 to 5 individual female Buccinum undatum, all collected in 1997 or 1998, were analysed. Organotin concentrations in the bivalves Arctica islandica and Nuculana pernula from a few stations were determined in addition. The tissue was chemically digested in $1 \mathrm{~N} \mathrm{HCl}$ followed by $\mathrm{pH}$ adjust-

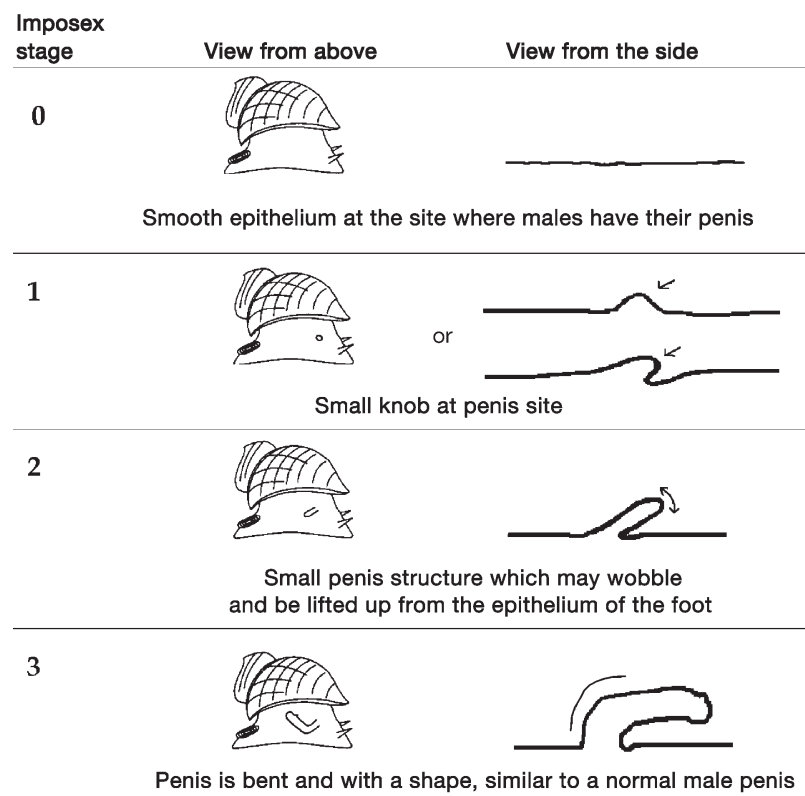

Fig. 3. Buccinum undatum. Penis Classification Index (PCI). Imposex stages are increased by 0.5 points when a vas deferens is present. Modified from Mensink et al. (1997)

Table 1. Buccinum undatum and Neptunea antiqua. Sampling stations, and imposex intensities given as frequency (\%), Vas Deferens Sequence Index (VDSI) and Penis Classification Index (PCI). Stations: (1) Skagerrak, (2) Kristineberg, (3) Anholt, (4) Stor Middelgrund, (5) Hallands Väderö, (6) Gilleleje, (7) Tisvildeleje, (8) Hesselø, (9) Sjællands odde, (10) Schultz' grund, (11) Vejrø,

(12) North of Sprogø, (13) South of Sprogø, (14) Helsingør

\begin{tabular}{|c|c|c|c|c|c|c|c|c|c|c|c|}
\hline \multirow{2}{*}{ Stn } & \multirow{2}{*}{ Position } & \multirow{2}{*}{$\begin{array}{c}\text { Sampling } \\
\text { date } \\
\text { (dd/mm/yy) }\end{array}$} & \multirow{2}{*}{$\begin{array}{l}\text { Depth } \\
\text { (m) }\end{array}$} & \multicolumn{4}{|c|}{- Buccinum undatum } & \multirow{2}{*}{$\begin{array}{c}\mathrm{n} \text { fem./ } \\
\text { males }\end{array}$} & \multicolumn{2}{|c|}{ - Neptunea antiqua } & \multirow[b]{2}{*}{$\mathrm{PCl}$} \\
\hline & & & & $\begin{array}{l}\mathrm{n} \text { fem./ } \\
\text { males }\end{array}$ & $\begin{array}{c}\text { Imposex } \\
\text { frequency }(\%)\end{array}$ & VDSI & PCI & & $\begin{array}{c}\text { Imposex } \\
\text { frequency }(\%)\end{array}$ & VDSI & \\
\hline 1 & $\begin{array}{l}57^{\circ} 48^{\prime} \mathrm{N} \\
10^{\circ} 11^{\prime} \mathrm{E}\end{array}$ & $19 / 7 / 97$ & $70-77$ & $16 / 16$ & 31 & 0.7 & 0.8 & $24 / 47$ & 67 & 1.8 & 1.5 \\
\hline 2 & $\begin{array}{l}58^{\circ} 15^{\prime} \mathrm{N} \\
11^{\circ} 26^{\prime} \mathrm{E}\end{array}$ & $18 / 5 / 97$ & $10-20$ & $9 / 10$ & 89 & 1.3 & 1.9 & $5 / 6$ & 100 & 4.0 & 3.3 \\
\hline 3 & $\begin{array}{l}56^{\circ} 50^{\prime} \mathrm{N} \\
11^{\circ} 53^{\prime} \mathrm{E}\end{array}$ & $7 / 6 / 97$ & $19-40$ & $18 / 20$ & 22 & 0.3 & 0.5 & $2 / 7$ & 100 & 4.0 & 2.0 \\
\hline 4 & $\begin{array}{l}56^{\circ} 32^{\prime} \mathrm{N} \\
12^{\circ} 04^{\prime} \mathrm{E}\end{array}$ & $11 / 8 / 97$ & $10-21$ & $22 / 23$ & 36 & 0.6 & 0.6 & $0 / 1$ & - & - & - \\
\hline 5 & $\begin{array}{l}56^{\circ} 34^{\prime} \mathrm{N} \\
12^{\circ} 33^{\prime} \mathrm{E}\end{array}$ & $\begin{array}{c}7 / 6 / 97 \\
30 / 4 / 98\end{array}$ & $22-27$ & $11 / 12$ & 9 & 0.1 & 0.1 & $5 / 6$ & 100 & 4.0 & 2.7 \\
\hline 6 & $\begin{array}{l}56^{\circ} 10^{\prime} \mathrm{N} \\
12^{\circ} 24^{\prime} \mathrm{E}\end{array}$ & $\begin{array}{c}6 / 6 / 97 \\
27 / 4 / 98\end{array}$ & $24-25$ & $40 / 34$ & 20 & 0.2 & 0.3 & $11 / 13$ & 100 & 3.5 & 2.7 \\
\hline 7 & $\begin{array}{l}56^{\circ} 14^{\prime} \mathrm{N} \\
11^{\circ} 56^{\prime} \mathrm{E}\end{array}$ & $\begin{array}{c}6 / 6 / 97 \\
27 / 4 / 98\end{array}$ & $27-28$ & $17 / 27$ & 12 & 0.1 & 0.1 & $5 / 4$ & 100 & 3.8 & 2.3 \\
\hline 8 & $\begin{array}{l}56^{\circ} 09^{\prime} \mathrm{N} \\
11^{\circ} 41^{\prime} \mathrm{E}\end{array}$ & $\begin{array}{c}6 / 6 / 97 \\
27 / 4 / 97\end{array}$ & $20-24$ & $32 / 46$ & 34 & 0.5 & 0.5 & $12 / 17$ & 100 & 3.7 & 2.3 \\
\hline 9 & $\begin{array}{l}56^{\circ} 07^{\prime} \mathrm{N} \\
11^{\circ} 14^{\prime} \mathrm{E}\end{array}$ & $28 / 4 / 98$ & $17-29$ & $31 / 67$ & 10 & 0.1 & 0.1 & $6 / 3$ & 100 & 4.0 & 3.2 \\
\hline 10 & $\begin{array}{l}56^{\circ} 08^{\prime} \mathrm{N} \\
11^{\circ} 08^{\prime} \mathrm{E}\end{array}$ & $\begin{array}{c}6 / 6 / 97 \\
13 / 8 / 97\end{array}$ & $11-18$ & $32 / 25$ & 9 & 0.1 & 0.1 & $45 / 39$ & 100 & 3.2 & 2.3 \\
\hline 11 & $\begin{array}{l}55^{\circ} 56^{\prime} \mathrm{N} \\
10^{\circ} 46^{\prime} \mathrm{E}\end{array}$ & $\begin{array}{c}8 / 6 / 97 \\
14 / 8 / 97\end{array}$ & $13-21$ & $12 / 11$ & 67 & 1.0 & 1.2 & $6 / 1$ & 100 & 4.0 & 2.8 \\
\hline 12 & $\begin{array}{l}55^{\circ} 23^{\prime} \mathrm{N} \\
10^{\circ} 58^{\prime} \mathrm{E}\end{array}$ & $\begin{array}{l}5 / 6 / 96 \\
5 / 6 / 97\end{array}$ & $22-35$ & $21 / 26$ & 33 & 0.4 & 0.5 & $3 / 0$ & 100 & 4.0 & 2.5 \\
\hline 13 & $\begin{array}{l}55^{\circ} 18^{\prime} \mathrm{N} \\
11^{\circ} 00^{\prime} \mathrm{E}\end{array}$ & 20/8/97 & $23-30$ & $13 / 12$ & 85 & 1.6 & 1.7 & $5 / 9$ & 100 & 4.0 & 3.3 \\
\hline 14 & $\begin{array}{l}56^{\circ} 03^{\prime} \mathrm{N} \\
12^{\circ} 39^{\prime} \mathrm{E}\end{array}$ & 28/11/97 & 25 & $9 / 10$ & 44 & 0.7 & 0.7 & $1 / 1$ & 100 & 4.0 & 2.5 \\
\hline
\end{tabular}


Table 2. Neptunea antiqua. Imposex frequency (no. of females) in the Kattegat before 1938, Skagerrak 1997 (Stn 1) and Kattegat 1996-98 (all stations except Stns 1 and 2)

\begin{tabular}{|lrcc|}
\hline & $\begin{array}{c}\text { With } \\
\text { imposex }\end{array}$ & $\begin{array}{c}\text { Without } \\
\text { imposex }\end{array}$ & VDSI \\
\hline Kattegat $(<1938)$ & 0 & 6 & 0.0 \\
Skagerrak (1997) & 18 & 6 & 1.8 \\
Kattegat (1996-98) & 101 & 0 & 3.7 \\
\hline
\end{tabular}

ment ( $\mathrm{pH} \approx 5$ ), ethylation of the organotin compounds with sodium tetraethylborate and extraction to npentane. Tripropyltin was added as internal standard. The organotin concentrations were determined by CGC-PFPD (capillary gas chromatography-pulsed flame photometric detection) (Jacobsen et al. 1997). The organotin compounds detected were tributyltin (TBT), dibutyltin (DBT), monobutyltin (MBT), triphenyltin (TPhT), diphenyltin (DPhT) and monophenyltin (MPhT). The detection limits for butyltin and phenyltin compounds were 0.2 and $1.0 \mathrm{ng} \mathrm{Sn} \mathrm{g}^{-1}$ wet wt, respectively, and the overall analytical reproducibility was within $\pm 15 \%$ for butyltins and $\pm 20 \%$ for phenyltins. The analyses of the certified reference material BCR 477 gave recoveries of $110.2 \pm 5.4 \%$ for TBT, $108.6 \pm$ $9.2 \%$ for DBT, and $92.6 \pm 10.3 \%$ for MBT. Phenyltin concentrations in BCR 477 were not certified. The dry weight content of whelks was $22.5 \pm 3.8 \%$ of the wet weight.

\section{RESULTS \\ Imposex levels in Buccinum undatum and Neptunea antiqua}

Imposex was present in both species at all stations, although it was more frequent and more pronounced in Neptunea antiqua than in Buccinum undatum (Table 1). In $B$. undatum the imposex frequency varied from 9 to $89 \%$ in the different areas. Increased levels of imposex in $B$. undatum were found at 3 of the stations with $\geq 67 \%$ imposex and VDSI values $>1.0$. The observed imposex stages in $B$. undatum were characterised as VDSI Stages 1a, 1b, 2a and 3a. The largest penis homologue $(21 \mathrm{~mm}$ in length, plus a fragment of a vas deferens, VDSI Stage 3a) was in a female whelk from the Skagerrak (Stn 1).

In Neptunea antiqua all females from the Kattegat area had developed imposex. The majority was characterised as VDSI Stages 4 and $4+$, but VDSI Stages 1a, 1c, 2a, 2b, 2c, 3a, 3b and 3c were observed as well. Stage $4+$ is assigned a value of 4 in the calculations of VDSI. In addition to imposex, 9 of the 101 females of $N$. antiqua caught in the Kattegat had developed a curled oviduct between the ovary and the pallial oviduct, almost similar in appearance to a male seminal vesicle. This stage may be characterised as being beyond Stage 4+. Oehlmann et al. (1991) describe this as a further alteration of the female genital system. Because of a limited number

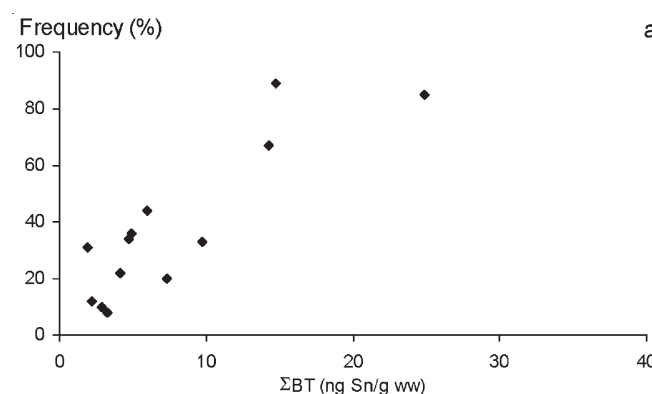

a)

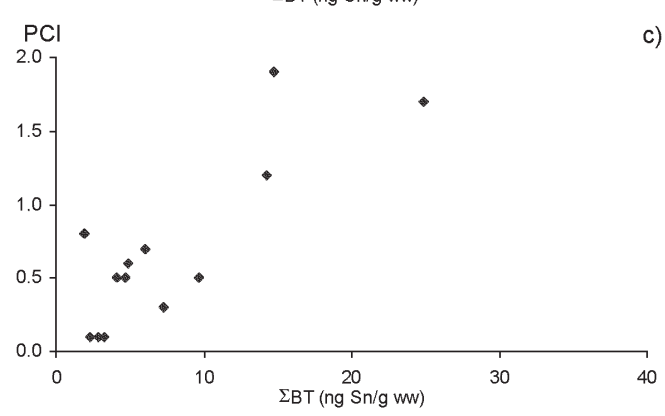

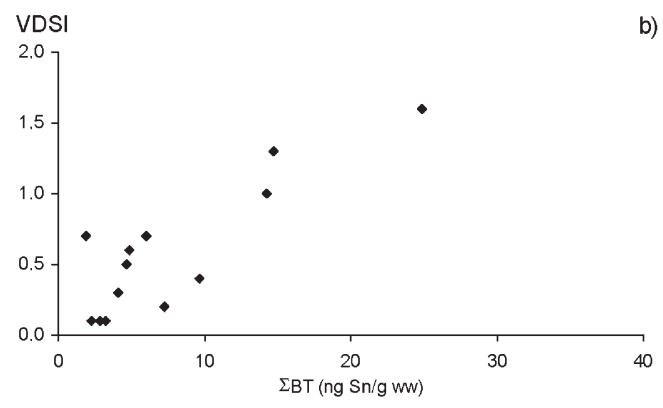

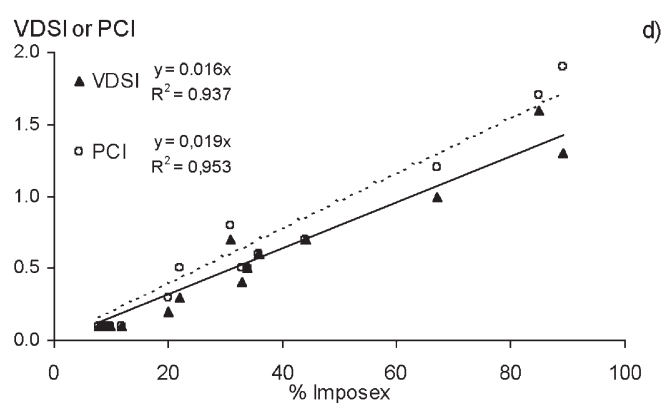

Fig. 4. Buccinum undatum. Spearman rank correlation analysis ( $\mathrm{n}=13$ stations) of average concentrations of total butyltin ( $\left.\sum \mathrm{BT}\right)$ to: (a) imposex frequency $\left(\mathrm{r}_{\mathrm{s}}=0.769, \mathrm{p}<0.01\right)$; (b) Vas Deferens Sequence Index (VDSI) $\left(\mathrm{r}_{\mathrm{s}}=0.664, \mathrm{p}<0.05\right)$; and (c) Penis Classification Index (PCI) $\left(r_{s}=0.637, p<0.05\right)$. (d) Frequency of imposex versus VDSI and PCI 
Table 3. Buccinum undatum. Organotin concentrations (ng Sn $\mathrm{g}^{-1}$ wet wt) in soft tissues. $\mathrm{n}=$ no. of samples

\begin{tabular}{|c|c|c|c|c|c|}
\hline Stn & $\mathrm{n}$ & $\begin{array}{c}\text { TBT } \\
\text { average (range) }\end{array}$ & $\begin{array}{c}\text { DBT } \\
\text { average (range) }\end{array}$ & $\begin{array}{c}\text { MBT } \\
\text { average (range) }\end{array}$ & $\begin{array}{c}\sum \mathrm{BT} \\
\text { average (range) }\end{array}$ \\
\hline 1 & 2 & $0.1(<0.2-0.2)$ & $1.6(1.2-2.0)$ & $0.2(<0.4-0.4)$ & $1.9(1.2-2.6)$ \\
\hline 2 & 3 & $2.5(1.4-3.1)$ & $10.7(5.4-17.1)$ & $1.5(<0.5-3.9)$ & $14.7(8.3-22.4)$ \\
\hline 3 & 3 & $0.4(<0.2-0.7)$ & $2.7(2.0-3.1)$ & $1.2(<0.4-2.6)$ & $4.2(2.9-6.3)$ \\
\hline 4 & 1 & 0.5 & 3.0 & 1.4 & 4.9 \\
\hline 6 & 3 & $0.7(0.6-0.8)$ & $5.9(5.7-6.0)$ & $0.7(0.2-2.1)$ & $7.3(6.5-8.7)$ \\
\hline 7 & 2 & $0.3(0.2-0.4)$ & $1.3(1.1-1.5)$ & $0.5(0.5)$ & $2.1(2.0-2.2)$ \\
\hline 8 & 1 & 1.0 & 2.7 & 1.0 & 4.7 \\
\hline 9 & 1 & 0.3 & 1.9 & 0.7 & 2.9 \\
\hline 10 & 1 & 0.6 & 1.8 & 0.9 & 3.3 \\
\hline 11 & 2 & $1.6(1.1-2.0)$ & $9.9(8.4-11.3)$ & $2.9(2.3-3.5)$ & $14.3(12.7-15.9)$ \\
\hline 12 & 3 & $1.3(0.7-2.0)$ & $6.1(2.2-9.2)$ & $2.0(0.9-3.9)$ & $9.4(3.8-12.4)$ \\
\hline 13 & 3 & $1.6(1.1-2.1)$ & $17.0(10.6-22.6)$ & $6.2(4.9-8.7)$ & $24.9(16.9-32.9)$ \\
\hline 14 & 1 & 1.2 & 2.2 & 2.6 & 6.0 \\
\hline
\end{tabular}

of $N$. antiqua from the Kattegat, a weighted average of VDSI stages in all $N$. antiqua from all Kattegat stations was calculated and compared to $N$. antiqua from the Skagerrak (Table 2). The intensity of imposex was much more severe in the southern Kattegat (VDSI = 3.7) than in the Skagerrak (VDSI = 1.8). In the reference material of $N$. antiqua collected in 1900 to 1938 from the Kattegat, none of the 6 females had imposex, in contrast to the situation today, where all females have developed imposex (Table $2 ; \chi^{2}=80.3$, $\mathrm{p}<0.01,2 \times 2$ contingency table) .

\section{Organotin levels and imposex}

Butyltin compounds were found in Buccinum undatum from all sampling stations; body burdens of TBT ranged from $<0.2$ to $3.1 \mathrm{ng} \mathrm{Sn} \mathrm{g}^{-1}$ wet $\mathrm{wt}_{\text {, and total }}$ butyltin $\left(\sum \mathrm{BT}=\mathrm{TBT}+\mathrm{DBT}+\mathrm{MBT}\right)$ ranged from 1.2 to $32.9 \mathrm{ng} \mathrm{Sn} \mathrm{g}^{-1}$ wet wt (Table 3). The lowest $\sum \mathrm{BT}$ concentrations were in whelks from the Skagerrak (Stn 1) with an average of $1.9 \mathrm{ng} \mathrm{Sn}^{-1}$ wet wt, and the highest $\sum$ BT concentrations were south of Sprogø (Stn 13) with an average of $24.9 \mathrm{ng} \mathrm{Sn} \mathrm{g}^{-1}$ wet wt. $B$. undatum is thought to biotransform TBT to DBT and MBT (Ide et al. 1997), and in all samples TBT forms a minor part of the $\sum B T$ content. The ratio of TBT to $\sum B T$ in the whelks varied from 0.05 to 0.34 . DBT was the principal component in all samples. Phenyltin compounds were only detected at Stn 2 (TPhT: 1.4 to $6.4 \mathrm{ng} \mathrm{Sn} \mathrm{g}^{-1}$ wet $\mathrm{wt}_{\text {; }}$ DPhT: $<1.0$ to $1.6 \mathrm{ng} \mathrm{Sn}{ }^{-1}$ wet $\mathrm{wt}_{\text {; }} \mathrm{MPhT}$ : $<1.3 \mathrm{ng} \mathrm{Sn}$ $\mathrm{g}^{-1}$ wet wt) and Stn 13 (TPhT: $<1$ to $2.3 \mathrm{ng} \mathrm{Sn} \mathrm{g}^{-1}$ wet wt; DPhT: $<1 \mathrm{ng} \mathrm{Sn} \mathrm{g}^{-1}$ wet wt; MPhT: $<1$ to $1.9 \mathrm{ng} \mathrm{Sn}$ $\mathrm{g}^{-1}$ wet wt).

The frequency of imposex as well as VDSI and PCI in Buccinum undatum are significantly correlated to

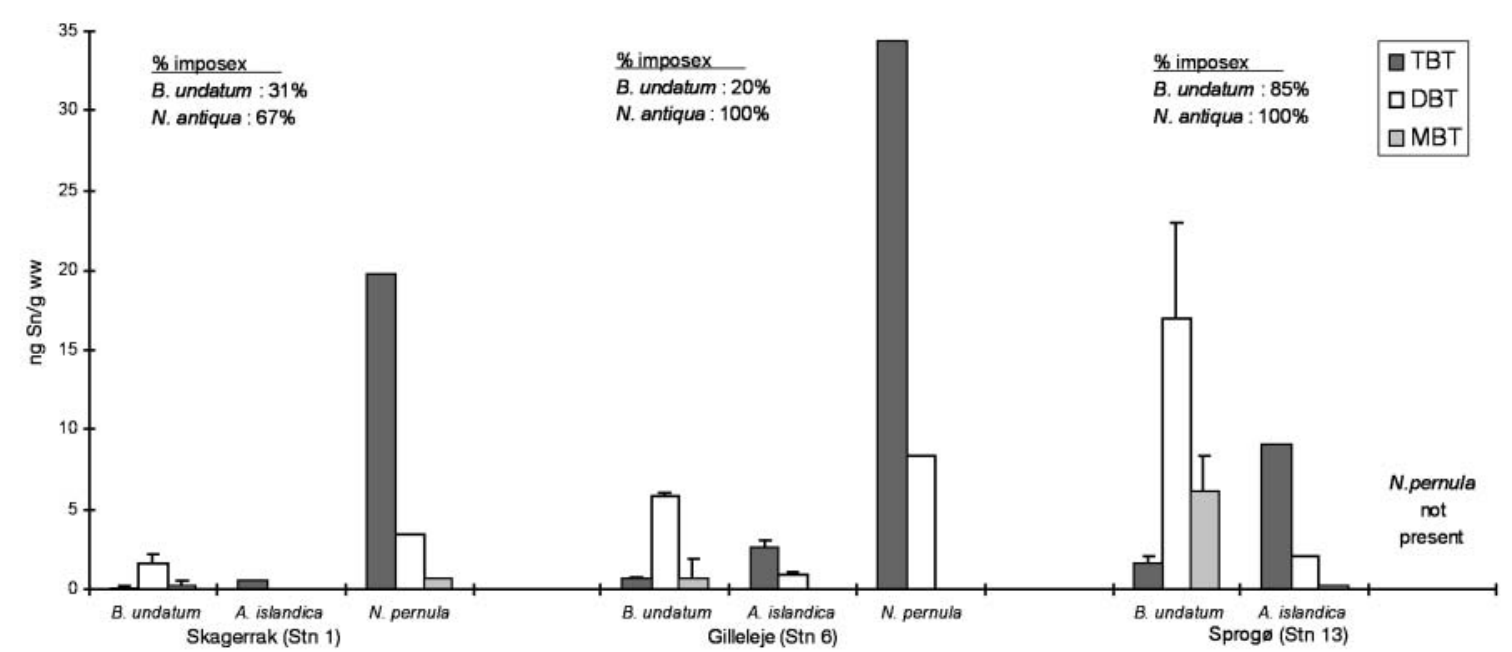

Fig. 5. Buccinum undatum, Arctica islandica and Nuculana pernula. Organotin concentrations at 3 stations in Danish waters. Frequencies of imposex in B. undatum and Neptunea antiqua are listed above the columns. SD (vertical lines) shown when $\mathrm{n}>1$ 
tissue concentrations of butyltin (Fig. $4 \mathrm{a}-\mathrm{c}$ ). The best correlation was established between the intensity of imposex and body burdens of $\Sigma \mathrm{BT}$, but significant positive correlations were also achieved by using TBT only.

The intensity of imposex in Buccinum undatum was relatively high at the Skagerrak (Stn 1) compared to the Kattegat stations, but this was not reflected in the organotin levels, which were comparatively low. A similar situation applied to the suspension-feeding bivalve Arctica islandica and the deposit-feeding bivalve Nuculana pernula collected at the same stations (Fig. 5). The frequency of imposex in $N$. antiqua was, however, lower at the Skagerrak station than at the Kattegat station used for comparison.

\section{DISCUSSION}

The presence of imposex and TBT at all stations reflects the ubiquity of TBT. This study finds significant correlations between organotin concentrations and intensity of imposex (frequency, VDSI and PCI) in Buccinum undatum, indicating that $B$. undatum is a useful bioindicator of TBT. It cannot be established, based on these data, which of the imposex criteria most appropriately describes the impact of organotin levels.

VDSI and PCI are more informative than frequency alone, as they provide a measure of the severity of imposex, but frequency, VDSI and PCI are not independent measures within this range of imposex as they are strongly correlated to each other (Fig. 4d). We found only a small difference between VDSI and PCI for Buccinum undatum in the different areas and the usefulness of PCI as a new measure of imposex in $B$. undatum may therefore be limited. In this study, VDSI and PCI values higher than 1 occurred at 3 stations, and they were all related to increased organotin levels. At lower imposex levels this relationship was not found. This is similar to the observations in a study from the open North Sea (Ide et al. 1997). Absence of imposex in $B$. undatum has only been observed in few areas of the North Sea (ten Hallers-Tjabbes et al. 1994, 1996, Ide et al. 1997, Nicholson \& Evans 1997).

However, imposex development is irreversible and need not reflect present TBT concentrations. Because of the whelks' capability to biotransform and eliminate TBT and because of resting periods in feeding uptake, the intensity of imposex could represent a temporary TBT exposure. In laboratory experiments with Buccinum undatum, TBT induced imposex in juveniles, but had no impact on adults exposed for 9 mo (Mensink et al. 1996a). Imposex will therefore in general reflect TBT exposure that took place some years earlier. This may be the reason for low correlations between TBT concentrations and imposex in open waters. Seasonal fluctuations in environmental TBT concentrations may play a role as well.

At 2 of the stations with increased imposex intensities (VDSI > 1), phenyltin compounds were detected as well. A study from the Eastern Scheldt in the Netherlands found high TPhT levels in an area with intense imposex development in Buccinum undatum (Mensink et al. 1996b), and TPhT may influence imposex development as well.

The presence of imposex was greater in Neptunea antiqua than in Buccinum undatum. Since all females of $N$. antiqua from the Kattegat and the majority of females from the Skagerrak were affected, this species is probably a more sensitive indicator of TBT pollution. In our study, imposex occurred more frequently than in the populations of $N$. antiqua from the North Sea, where 0 to $29 \%$ of the individuals had developed imposex (ten Hallers-Tjabbes et al. 1996, Ide et al. 1997). This suggests increased levels of TBT in Danish waters. At present, N. antiqua seems too sensitive for distinguishing between the different TBT levels in inshore waters, since imposex is most intensive at all areas, with VDSI values close to the maximum of 4.0 (Table 1). B. undatum has another advantage as a bioindicator in the Kattegat than $N$. antiqua, because it is generally more common.

No imposex was present in 6 females of Neptunea antiqua collected in the Kattegat before 1938, so that the widespread imposex phenomenon is likely due to a recent anthropogenetic factor such as TBT, which was introduced to the marine environment in the 1960s (Clark et al. 1988). Similar indications can be deduced from 2 earlier Danish studies. In 1967, 126 female $N$. antiqua sampled in The Sound between Denmark and Sweden near Stn 6 had no traces of a penis (Pearce \& Thorson 1967). Today, all females of $N$. antiqua bear a penis in this area. Buccinum undatum $(\mathrm{n}=1700)$ were investigated for parasites in 1967 in 2 areas (near Stns 2 and 6), and no females had developed a pseudopenis, i.e. imposex, due to infection by trematodes (Køie 1969). Today imposex is present in infected as well as non-infected females of $B$. undatum from both stations.

Whether the fertility and thereby the population sizes and distributions of Buccinum undatum and Neptunea antiqua have been affected by imposex was not determined by our study. Subadults of both species were present at all stations, even in areas with high intensities of imposex. This indicates that the populations still reproduce. Neither B. undatum nor $N$. antiqua have a pelagic larval stage, so that an exchange between different areas will presumably occur slowly. In the North Sea area, populations of $B$. undatum have markedly declined in the last decades, but factors other than TBT and imposex (e.g. beam trawling for 
fish, and commercial fishery on whelks) have to be taken into account (ten Hallers-Tjabbes et al. 1996). Surveys of imposex in Buccinum undatum and Neptunea antiqua will be implemented in the marine part of the national monitoring programme in Denmark, NOVA 2003 in coming years.

Acknowledgements. The divers K. Dahl and J. Damgård and the crews on RV 'Gunnar Thorson' and RV 'Dana' are kindly acknowledged for their assistance in collecting the whelks. We thank Dr. G. Høpner Petersen for access to the conserved whelks from the Kattegat area from the collection of marine gastropods at the Danish Zoological Museum in Copenhagen. We thank B. P. Mensink from the Netherlands Institute for Sea Research (NIOZ) for fruitful collaboration and discussion on imposex determination. This project was a spin-off from a project of the Nordic Council of Ministers.

\section{LITERATURE CITED}

Blaber SJM (1970) The occurrence of a penis-like outgrowth behind the right tentacle in spent females of Nucella lapillus. Proc Malacol Soc Lond 39:231-233

Clark EA, Sterritt RM, Lester JN (1988) The fate of tributyltin in the aquatic environment. Environ Sci Technol 22(6): 600-604

Danmarks Statistik (1997) Observerede skibspassager gennem Sund og Bælt. In: Statistical Yearbook. Stiftsbogtrykkerie, Aarhus (in Danish)

Evans SM, Leksono T, McKinnell PD (1995) Tributyltin pollution: a diminishing problem following legislation limiting the use of TBT-based antifouling paints. Mar Pollut Bull 30(1):14-21

Gibbs PE, Bryan GW, Pascoe PL, Burt GR (1987) The use of the dog-whelk, Nucella lapillus, as an indicator of tributyltin (TBT) contamination. J Mar Biol Assoc UK 67: 507-523

Ide I, Witten EP, Fisher J, Kalbfus W, Zellner A, Stroben E, Watermann B (1997) Accumulation of organotin compounds in the common whelk Buccinum undatum and the red whelk Neptunea antiqua in association with imposex. Mar Ecol Prog Ser 152:197-203

Jacobsen JA, Stuer-Lauridsen F, Pritzl G (1997) Organotin speciation in environmental samples by capillary gas

Editorial responsibility: Otto Kinne (Editor),

Oldendorf/Luhe, Germany chromatography and pulsed flame photometer detection (PFPD). Appl Organomet Chem 11:737-741

Køie M (1969) On the endoparasites of Buccinum undatum L. with special reference to the trematodes. Ophelia 6: 251-279

Matthiessen P, Gibbs PE (1998) Critical appraisal of the evidence for tributyltin-mediated endocrine disruption in molluscs. Environ Toxicol Chem 17:37-43

Mensink BP, Everaarts JM, Kralt J, ten Hallers-Tjabbes CC, Boon JP (1996a) Tributyltin exposure in early life stages induces the development of male sexual characteristics in the common whelk, Buccinum undatum. Mar Environ Res 42(1):151-154

Mensink BP, ten Hallers-Tjabbes CC, Kralt J, Freriks IL, Boon JP (1996b) Assessment of imposex in the common whelk, Buccinum undatum (L.) from the Eastern Scheldt, the Netherlands. Mar Environ Res 41(4):315-325

Mensink BP, van Hattum B, ten Hallers-Tjabbes CC, Everaarts JM, Kralt H, Vethaak AD, Boon JP (1997) Tributyltin causes imposex in the common whelk, Buccinum undatum: mechanism and occurrence. Netherlands Institute for Sea Research (NIOZ), Rapport 6, Den Burg, Texel

Nicholson GJ, Evans SM (1997) Anthropogenic impacts on the stocks of the common whelk Buccinum undatum (L.). Mar Environ Res 44(3):305-314

Oehlmann J, Stroben E, Firioni P (1991) The morphological expression of imposex in Nucella lapillus (Linnaeus) (Gastropoda: Muricidae). J Molluscan Stud 57:375-390

Oehlmann J, Stroben E, Schulte-Oehlmann U, Bauer B, Firioni P, Markert B (1996) Tributyltin biomonitoring using prosobranch as sentinel organism. Fresenius J Anal Chem 354:540-545

Pearce JB, Thorson G (1967) The feeding and reproductive biology of the red whelk, Neptunea antiqua (L.) (Gastropoda, Prosobranchia). Ophelia 4:277-314

Smith BS (1971) Sexuality in the american mud snail, Nassarius obsoletus Say. Proc Malacol Soc Lond 39:377-378

Stroben E, Oehlmann J, Fioroni P (1992) The morphological expression of imposex in Hinia reticulata (Gastropoda: Buccinidae): a potential indicator of tributyltin pollution. Mar Biol 113:625-636

ten Hallers-Tjabbes CC, Kemp JK, Boon JP (1994) Imposex in whelks (Buccinum undatum) from the open North Sea: Relating to shipping traffic intensities. Mar Pollut Bull 28(5):311-313

ten Haller-Tjabbes CC, Everaarts JM, Mensink BP, Boon JP (1996) The decline of the North Sea whelk (Buccinum undatum L.) between 1970 and 1990: a natural or a human-induced event? PSZN I: Mar Ecol 17(1-3):333-343

Submitted: February 8, 1999; Accepted: August 9, 2002 Proofs received from author(s): November 8, 2002 